УДК 371.333:616-083.98

\title{
ОСОБЛИВОСТІ ДИСТАНЦЙНОГО ВИКЛАДАННЯ ДИСЦИПЛІНИ “НЕВІДКЛАДНІ СТАНИ" ДЛЯ СТУДЕНТІВ-МЕДСЕСТЕР НА КАФЕДРІ НЕВІДКЛАДНОЇ ТА ЕКСТРЕНОЇ МЕДИЧНОЇ ДОПОМОГИ ТДМУ ІМ. І. Я. ГОРБАЧЕВСЬКОГО
}

О. Л. Сидоренко ДВНЗ “Тернопільський державний медичний університет імені І. Я. Горбачевського МОЗ Украйни”

\section{THE PECULIARITIES OF DISTANCE LEARNING IN DISCIPLINE OF EMERGENCY CARE FOR NURSING STUDENTS AT EMERGENCY CARE DEPARTMENT OF TSMU BY I. YA. HORBACHEVSKY}

O. L. Sydorenko

SHEI “Ternopil State Medical University by I. Ya. Horbachevsky of MPH of Ukraine”

\begin{abstract}
У статті наведені особливості дистанційного викладання дисципліни “Невідкладні стани" для студентів-медсестер, що полягас у створенні деталізованих спеціалізованих алгоритмів надання невідкладної допомоги. Вказано на перспективи впровадження дистанційної освіти у даної категорії студентів.
\end{abstract}

The articles describes the peculiarities of distance learning in discipline of Emergency Care for nursing students, which consist in the creation of detailed specialized algorithms of emergency care. It was established the perspectives of distance education implementation in nursing students.

Вступ. В останні роки швидкий розвиток інформаційних технологій потребує модернізації в системі освіти, в тому числі і медичної. Суть цієї модернізації відобразилась найбільше в концепції дистанційного навчання (ДН), яке, завдяки всесвітній мережі Інтернет, охоплює широкі верстви населення та стає важливим рушієм його розвитку.

ДН передбачає таку організацію навчального процесу, коли студент навчається самостійно за розробленою викладачем програмою і віддалений від нього у просторі та часі, однак може вести з ним діалог за допомогою засобів телекомунікації $[1,2]$. Дистанційна освіта стала надзвичайно популярною формою навчання завдяки своїй зручності й гнучкості. Вона усуває основний бар'єр, що утримує багатьох професіоналів від продовження освіти, рятуючи від необхідності відвідувати заняття за встановленим розкладом. Студенти дистанційно можуть вибирати зручний для себе час занять відповідно до власного розкладу. Також ДН є економічно вигідним з матеріальної точки зору як для навчальних установ (відсутня необхідність у додаткових приміщеннях, гуртожитках для студентів), так і для самих студентів, що зберегли можливість працювати і в той же час повноцінно навчатись у зруч- ний для них час (поєднуючи навчання з робочими обов'язками) [3]. А завдяки низці нормативних документів $[4,5,6]$ ДН набуває все більшого визнання у вищих навчальних закладах України.

Основна частина. Тому метою нашої роботи було вивчення ефективності дистанційної форми навчання у викладанні дисципліни “Невідкладні стани” для медсестер-магістрів на базі кафедри невідкладної та екстреної медичної допомоги Тернопільського державного медичного університету ім. І. Я. Горбачевського.

ДН є особливо актуальною формою навчання для медичної галузі. Медицина в Україні сьогодні потребує забезпечення безперервності підготовки спеціалістів, що $€$ головною складовою власне ступеневої освіти. І ДН може бути впроваджена власне для ступеневої освіти в медсестринстві, оскільки мова йде про кваліфікаційне удосконалення вже сформованих спеціалістів, дипломованих медичних сестер, які вжезакінчили навчальний заклад I-II рівня акредитації, мають певний досвід роботи та в силу певних обставин не можуть перебувати на очному навчанні тривало.

У квітні 2009 року вийшов наказ МОЗ України № 283 “Про удосконалення підготовки та підвищення кваліфікації медичних працівників 3 надання екст-

(c) О. Л. Сидоренко 
реної та невідкладної медичної допомоги", тому викладання даної дисципліни має нагальне та актуальне значення. Курс “Невідкладні стани” для медсестермагістрів викладається двома мовами (українська, англійська) на II курсі навчання і складається всього з 108 годин, з яких 10 годин лекцій, 62 години практичних занять та 36 годин самостійно-практичної роботи. Вид контролю - диференційований залік. Тематика як 5 лекцій, так 19 практичних занять включає в себе актуальні питання найпоширеніших невідкладних станів у клініці внутрішніх захворювань кардіології, пульмонології, ендокринології, нефрології, гастроентерології.

Методика ДН на нашій кафедрі, як і в університеті в цілому, передбачає створення для студента поштової скриньки на сервері університету та надання йому доступу до всіх навчально-методичних матеріалів навчальних програм, методичних вказівок, матеріалів підготовки до лекцій та практичних занять, презентацій лекцій. Варто зауважити, що всі лекції до дисципліни "Невідкладні стани" записані у спеціальному форматі, що поєднує відео з презентацією
PowerPoint. Водночас у студентів наявна можливість прослухати цю ж лекцію on-line через Skype, для чого слід напередодні записатись.

У більшості випадків практичну частину занять студент засвоює самостійно. Проте значно сприяють цьому цінні поради та консультації викладачів, в тому числі on-line. Для того щоб студент краще міг самостійно вивчити практичну навичку, нами деталізовано алгоритми ії освоєння. При цьому детально описується кожна дія медсестри, кожен рух, маніпуляція. Звичайно, надзвичайно корисними були б відеозаписи виконання практичних навичок, в тому числі і для практикуючих медсестер. Надалі ми плануємо додати такі відеоматеріали до усіх практичних занять, що допоможе студентам досконаліше освоїти ту чи іншу практичну навичку з надання невідкладної допомоги. Відеоматеріали повинні покроково продемонструвати кожен етап ії виконання.

Для прикладу наводимо алгоритм надання невідкладної допомоги при раптовій зупинці кровообігу (РЗК), оснований на універсальному алгоритмі спеціалізованих реанімаційних заходів (ALS) (рис. 1).

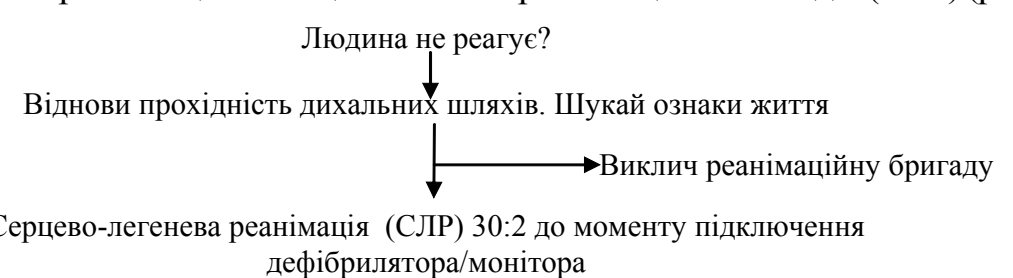
дефібрилятора/монітора

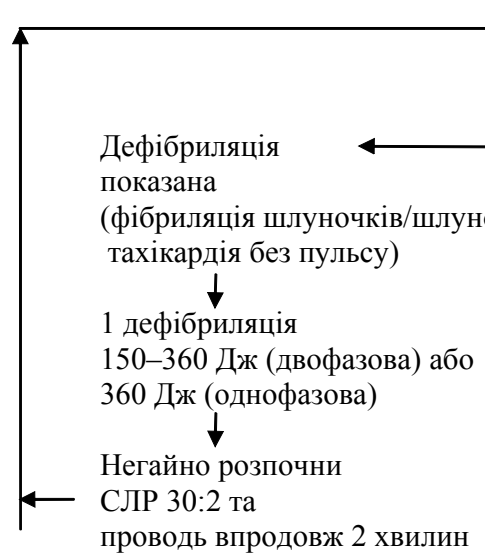

$\downarrow$

Puc. 1. Алгоритм спеціалізованих реанімаційних заходів при РЗК.

\section{Під час СЛР:}

- лікуй зворотні причини РЗК (гіпоксія, гіповолемія, гіпо/гіперкаліємія, метаболічні порушення, гіпотермія, напруженний пневмоторакс, тампонада серця, токсини, тромбоемболія (коронарна чи легенева));

- перевір розташування та контакт електродів;

- виконай/перевір: внутрішньовенний доступ, прохідність дихальних шляхів і кисневу терапію;

- не переривай натискань грудної клітки після забезпечення прохідності дихальних шляхів;

- вводь адреналін кожні 3-5 хвилин;

- при потребі застосуй аміодарон, атропін, магній. 
Висновок. Таким чином, дистанційна освіта $€$ власне тією формою навчання, перспективи розвитку якого спрямовані у майбутнє, іє при цьому позбавленою багатьох умовностей сучасного світу - в цілому не залежить ні від матеріального стану, ні від місця проживання, ні від стану здоров'я студента. Це є перспективний напрямок підвищення кваліфікаційного та наукового рівня мотивованої медсестри без відриву від основного місця роботи, в тому числі і іпри вивченні

\section{Література}

1. Денисов Д. О. Дистанційна освіта в Україні / Д. О. Денисов // Актуальні питання дистанційної освіти, порівняння сучасного стану дистанційної освіти в Україні та країнах Західної Європи : зб. наук. праць : у 2 ч. - Суми, 2004. - Ч. 1 : Педагогіка та методика навчання і виховання. - С. 44-48.

2. Жилінкова I. Дисертаційна освіта : комп'ютерні комунікації в сучасній освітній діяльності / I. Жилінкова // УПравління освітою. -2003 . - № 1. -4 лютого.

3. Jeanne Novotny M. Distance education in nursing / Jeanne M. Novotny, Robert H. Davis, editors. $-2^{\text {nd }}$ ed. -2006 , Springer Publishing. -256 p. дисципліни “Невідкладні стани”. Для кращого засвоєння даної дисципліни слід деталізувати спеціалізовані алгоритми надання невідкладної допомоги.

Проте слід пам'ятати, що ДН покладає певну відповідальність на студента, тому дана форма навчання буде ефективною власне для свідомих, дорослих студентів, які готові брати відповідальність за свій процес навчання не лише перед викладачем, але й, перш за все, перед самим собою.

4. Про затвердження Програми розвитку системи дистанційного навчання на 2004-2006 роки : Постанова Кабінету Міністрів України від 23 вересня 2003 р. № 1494 // Офіційний вісник України. - 2003. - № 39. - С. 8-13.

5. Про затвердження Заходів щодо реалізації Програми розвитку системи дистанційного навчання на 2004-2006 роки : наказ МОН України від 04.12.2003 р. № 802 // Відкритий урок. - 2004. - № 1/2. - С. 33.

6. Про затвердження Положення про дистанційне навчання : наказ МОН України від 21.01.2004 p. № 40 // Офіційний вісник України. - 2004. -№ 15. - С. 241-253. 